\title{
Professor Zdzisława Wójcik - life devoted to people and science
}

\author{
Karol Latowski
}

Department of Plant Taxonomy, Faculty of Biology, Adam Mickiewicz University, Umultowska 89, 61-614 Poznań, Poland, e-mail: latowski@amu.edu.pl

On 26 January 2015, Professor Zdzisława Wójcik celebrated a truly extraordinary anniversary - the $100^{\text {th }}$ anniversary of birthday. Earlier, in spring 2014, another respectable event took place, i.e., the $50^{\text {th }}$ anniversary of obtaining the $\mathrm{PhD}$ title. The complicated vicissitudes of her life abounded in various adverse situations that testified her strength and nobleness in difficult times. At the same time, she consistently developed her professional career with admirable persistence. Her interest in the world of nature started already in early childhood, in her home city of Kraków, where she was born and lived for many years. This was also the place in which her fascination for plants was born. Being a small girl, she was impressed by beauty of flowers growing in a home garden, in which, as she recalls, "my mother saw poppies. They were mostly red, but also pink, white and even yellow. And poppies were my greatest love. It turned out that the red colour was vital for my life". These feelings were so prophetic!

In spring 1920, family of Zdzisława Wójcik moved to Poznań, where her father - Kazimierz Wójcik - got employment as an associate professor of geology and paleontology at the newly founded, in 1919, University of Poznań. Here, she received a certificate of secondary education and began studies at the local university. She obtained the title of engineer of agriculture (1937) and, at the same time, the title of Master of Philosophy in the area of botany (1938). Both dissertation theses were subsequently published - in 1939 and 1938, respectively, which proves their high value. It is worth mentioning that she studied under the supervision of such famous botanists as: Feliks Krawiec, Witold Kulesza, Bronisław Niklewski, Józef Paczoski, Adam Wodziczko and Karol Zaleski. Owing to very good final marks obtained from the university and for the diploma theses, she was awarded with a scientific scholarship.
Within the framework of this scholarship, the studies of vegetation of the Brodnica Lakeland were initiated in summer 1939. Her research was soon stopped by an outbreak of the WW2.

The years 1939-1948 brought numerous life experiences connected with the hardships of war-time life and wandering, but they were also marked with great devotion and sacrifice during her stay in foreign lands. In June 1940, in Lvov, she was arrested and sent for forced labor to the surroundings of Arkhangelsk and Murmansk. After amnesty, Zdzisława Wójcik got employed in a diplomatic post in Arkhangelsk. In summer 1942, she leaved the Soviet Union together with a Polish army under general Władysław Anders. Initially, she worked for several months for the Polish Red Cross in Mashhad (Iran), supervising the transports of children to Teheran. Subsequently, she moved to the British East Africa, where, from December 1942 until the end of 1944, she managed all scout teams that were stationed there.

After the end of war, she worked for three years (1945-1947) as a biology and geography teacher in two high schools in Tenger in Tanganyika (presently Tanzania). At the same time, in her free time, she was a leader of a scout troop. Next, in February 1948, Zdzisława Wójcik left to Canada, where she got a position at the University of Toronto, as a research assistant. At the end of 1948, she returned to Poland and settled in Warsaw. Initially, she was engaged in various freelance jobs and, subsequently, in the years 1950-53, she was employed in the State Agricultural and Forestry Publishing House. At first, she took on a secretary position and, later, she was promoted to the position of editor and manager of the Editorial Office.

Due to her great respect for Józef Paczoski since student days, she edited "Dzieła wybrane" [The selected 


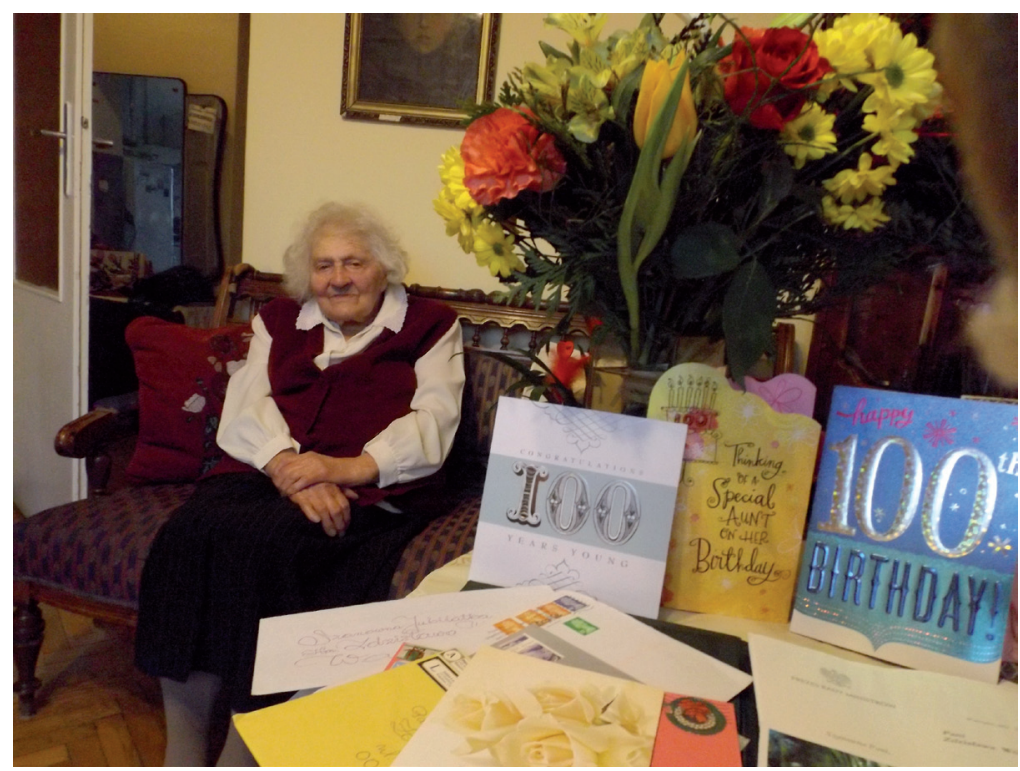

Fig. 1. Prof. Zdzisława Wójcik on the day of Her $100^{\text {th }}$ birthday (photograph by B. Wójcik)

works] of this eminent botanist. This publication is a reprint of significant works of Paczoski and contains "Szkice fitosocjologiczne" [Phytosociological drafts], "Podstawowe zagadnienia geografii roślin" [Fundamental issues of plant geography] and two early chapters of an extensive and thorough monograph "Lasy Białowieży" [Forests of Białowieża] - concerning "The ideological principles of phytosociology", and "Zagadnienia typologii leśnej" [Issues of forest typology]. The book was published in June 1951, i.e., on the eve of the First Congress of Polish Science, thus, proving the everlasting merits of Paczoski in building fundamentals of biocenosis science.
A return of Zdzisława Wójcik to a true scientific career, after almost 15 years of an unplanned break, can be counted since 1953, when she got a position in the Institute of Ecology of Polish Academy of Sciences. Here, she started from preliminary research of ecological literature. Effects of this work were published in 1953-55 in the journal "Ekologia Polska" [Polish Ecology]. In 1956, in the same journal, the summing up of this bibliography was issued as an extensive review of the Polish achievements in population science. The subsequent years of work in the Institute brought the whole series of both independent and team publications - the latter are prerequisite in interdisciplinary research.

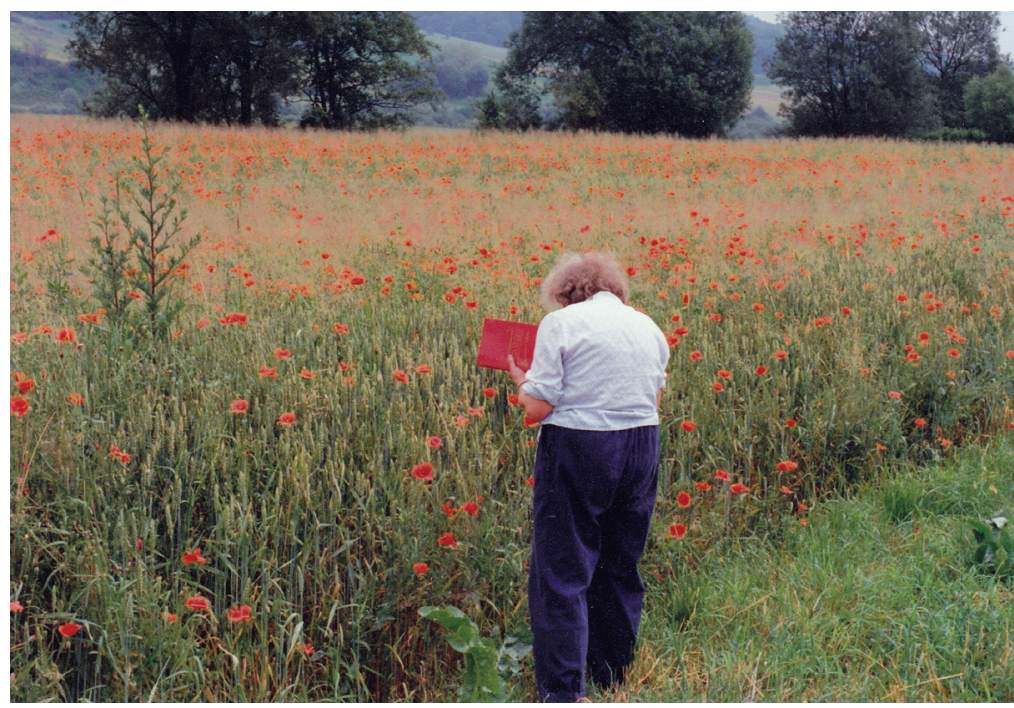

Fig. 2. Prof. Zdzisława Wójcik during field studies in the Przemyśl Foothills in 1992 (photograph by B. Wójcik) 
These works concentrated on the primary and secondary production of biomass in different terrestrial ecosystems (grasslands and forests). Particularly interesting were the results of field studies of invertebrate herbivore effects on grassland vegetation biomass, or the role of birds-vegetation interactions. Apart from the topics realized within the scope of the Institute, she conducted also the studies of weed vegetation in crop fields. In relation to the latter area of research, in April 1964, Zdzisława Wójcik was granted the title of Doctor of Philosophy by the Council of Faculty of Biology and Earth Sciences of Adam Mickiewicz University in Poznań, based on her $\mathrm{PhD}$ dissertation "Zbiorowiska chwastów zbożowych Mazowsza" [Crop weed communities of Mazowsze]. The thesis supervisor was prof. Zygmunt Czubiński.

In 1970, after moving to the Institute of Geography and Spatial Organization of the Polish Academy of Sciences, her studies concentrated on the issues of structure and functioning of segetal communities. She also continued ecological investigations related to the biomass production, determination of the role of insects in grassland ecosystems and functioning of ecotone zones. Zdzisława Wójcik paid also a lot of attention to the methodological aspects of research. She published numerous works that showed bioindicatory properties of plant associations and their use in the evaluation of environmental conditions. This area of research turned out to be very inspiring and fruitful. She proposed her work "Charakterystyka siedlisk polnych na Pogórzu Beskidu Niskiego metodami biologicznymi" [Characteristic of field habitats of the Low Beskid Foothills) as a basis of habilitation procedure. In 1976, she was awarded the degree of habilitated doctor in ecology and geobotany. It is also worth of mentioning that the reviewers of her dissertation were outstanding specialists, professors: Saturnin Borowiec, Jan Kornaś, Władysław Matuszkiewicz and Andrzej Samuel Kostrowicki. The novel qualities of this work were confirmed by the award of the Scientific Secretary of Polish Academy of Sciences, granted in 1976. A year later, the work was published. In the subsequent years, Prof. Wójcik conducted a thorough ecological analysis of the occurrence and differentiation of segetal weeds (of stubble fields, crops and root crops) in the crop fields of east regions of the country. She also investigated synanthropisation of forest islands in agricultural landscape. Moreover, the collected material and a great progress in general agroecological knowledge, related to the long standing program "Rejonizacja chwastów segetalnych w Polsce" [Regionalization of segetal weeds in Poland] coordinated by prof. Józef Rola (IUNG Wrocław), allowed her to investigate chorological topics. The outcome of these studies were works about the occurrence of Consolido-Brometum association, or distribution of species characteristic for Papaveretum argemones.

Prof. Wójcik has also rich and very valuable achievements in popularization of science. Her most important achievements in this area include scientific editing of joint translations of several handbooks, among others, of Elton (The ecology of invasions by animals and plants), Markov (Agrophytocoenology), Odum (Fundamentals of Ecology) and Tishler (Agroecology). She is also a co-author of a lengthy publication entitled "Kalendarz przyrody" [Calendar of nature] (1966), which aroused a great interest and had several editions in the years 1972-1995. Exceptional are also numerous publications by Prof. Wójcik that commemorate children deported to Soviet Union, who, subsequently, found their way to Middle East, Africa, India or New Zeland.

The overall achievement of Prof. Zdzisława Wójcik is very extensive and covers a number of topics. In total, it comprises about 100 positions and nearly half of them are original publications. These works are distinguished by great accuracy related to research material, methodological care and clear conclusions. The latest of these works were published in the years 2000-2001! One of them, i.e., "Zbiorowiska segetalne Pojezierza Suwalskiego" [Segetal communities of the Suwałki Lakeland] was a basis for awarding a special distinction. For this work, in 2001, she received the Medal of Professor Zygmunt Czubiński. Among other honorable distinctions, there should be mentioned the Medal of Commission of National Education for her didactic and educational work with schoolchildren in Africa.

Finally, one more 'corporate' distinction has to be acknowledged, which can be found in the special systematics of Polish researchers* involved in the studies of distribution, biology and ecology of segetal weeds, prepared by the author of the present article. In this system, Zdzisława Wójcik has been 'classified' as a nomenclatural type Exploratrix clarissima var. praeceptrix in the subclass Wójcikidae of the Mazovian subgroup (subgrex Mazoviensis).

Thus, the final thing to do is to pay a tribute to Professor Zdzisława Wójcik for her enormous merits and achievements and express our deep respect and admiration.

Our Dear and Honourable Jubilarian - we extend our heartfelt congratulations and wish you excellent health and everything the best. Ad multos annos!

*Latowski K. 2007. Segetalia Polonica - systema novum. Wiad. Bot. 51(3-4): 127-132. 


\section{Selected publications and other papers of Professor Zdzisława Wójcik in chronological order}

Niklewski B., Wójcikówna Z. \& Pestka M. 1939. Warunki rozwoju wyizolowanego końca korzenia. Acta Soc. Bot. Pol. 16(2): 81-125.

WósCik Z. 1965. Les associations des champs cultivés en Masovie. I. Les associations messicoles. Ekol. Pol. A. 13(30): 641-682.

Wóıсік Z. 1967. Evaluation of seed production and its relation to the total primary production of fields. International Studies on Sparrows. Progr. and methods 1: 18-22. Zakład Ekologii PAN, Warszawa.

Wóscik Z. 1968. Les associations des champs cultivés en Masovie. II. Les associations de chaumes de l'alliance Nanocyperion flavescentis. Ekol. Pol. A. 16(3): 101120.

WóJCIK Z. 1968. Udział apofitów i antropofitów w zbiorowiskach segetalnych Mazowsza. In: J. B. FALIŃSKI (ed.). Synantropizacja szaty roślinnej. I. Neofityzm i apofityzm w szacie roślinnej Polski. Materiały Zakładu Fitosocjologii Stosowanej UW 25: 109-124. Warszawa-Białowieża.

PinOwSKi J. \& WóJcik Z. 1968. Produkcja chwastów na polach i stopień wyżerowania ich nasion przez wróble polne (Passer montanus L.). Ekol. Pol. B. 14(3): 297-301.

Pinowski J. \& Wóscik Z. 1969. Die unkrautproduktion den feldern und die Ausnutzung des Unkrautsamens durch die Feldsperlinge. Der Falke. Vogelbeobachter 16: 256-261.

AndrZejewsKa L. \& Wóscik Z. 1970. The influence of Acridoidea on the primary production of a meadow (field experiment). Ekol. Pol. 18(5): 91-109.

WósCiK Z. 1970. Primary production of the herb layer and plant fall in a dry pine forest (Cladonio-Pinetum Kobendza 1930) in the Kampinos National Park. Ekol. Pol. 18(18): 393-409.

AndrZejewska L. \& Wóscik Z. 1971. Productivity investigation of two types of meadows in the Vistula Valley. VII. Estimation of the effect of phytophagous insects on the vascular plant biomass of the meadow. Ekol. Pol. 19 (13): 173-182.

Puszkar L., Traczyk T. \& Wóscik Z. 1972. Primary production of the herb layer and plant fall in the Vaccinio myrtilli-Pinetum forest association in the Pisz Forest (North-East Poland). Ekol. Pol. 20(22): 253-285.

Kostrowicki A. S. \& Wóscik Z. 1972. Podstawy teoretyczne i metodyczne oceny warunków przyrodniczych przy pomocy wskaźników roślinnych. In: Metody oceny warunków przyrodniczych produkcji rolniczej. Biuletyn Komitetu Przestrzennego Zagospodarowania Kraju PAN 71: 3-63. Warszawa.

WósCik Z. 1973. The plant communities of root-crops fields in lowlands and highlands of Poland: floristic, ecological and regional differentiation. Feddes Repert. 84(7-8): 573-588.

WóıcıK Z. 1973. Productivity of a sandy ryefield. Ekol. Pol. 21(23): 339-357.

Wóscik Z. 1974. Zbiorowiska roślinne pól uprawnych jako wyraz warunków siedliskowych w Beskidzie Niskim.
In: Rejonizacja chwastów segetalnych dla potrzeb rolnictwa. Wyd. Instytutu Uprawy, Nawożenia i Gleboznawstwa. R (82): 182-209. Puławy.

WósCIK Z. 1975. Versuch einer soziologisch-ökologischen und regionalen Gliederung der Segetalgesellschaften Poland. In: R. Schubert, W. Hilbig \& E. G. Mahn (eds.). Probleme der Agrogeobotanik. Wiss. Beitr. d. Marthin-Luther Univ. Halle-Wittenberg 11(P2): 31-32. Halle.

Wóscik Z. 1977. Charakterystyka siedlisk polnych na Pogórzu Beskidu Niskiego metodami biologicznymi. Prace Geograficzne Instytutu Geografii i Przestrzennego Zagospodarowania PAN 121: 7-111.

Wóscik Z. 1978. Plant communities of Poland's cereal fields. Preliminary results of comparative studies. Acta Bot. Slov. Acad. Sci. Slovacae. Ser. A. 3: 229-238. Bratyslawa.

Wóscik Z. 1980. Plant communities of Mazovian cultivated fields. III. Root-crop communities. Pol. Ecol. Stud. 6(3): 545-569.

WósciK Z. 1984. Consolido-Brometum in Northeastern Poland. Acta Bot. Slov. Acad. Sci. Slovacae. Ser. A. Suppl. 1: 327-339.

PawŁowski F., Jędruszczak M. \& Wójcik Z. 1989. Zbiorowiska roślinne ściernisk Lubelszczyzny. I. Zbiorowiska siedlisk ubogich. Acta Agrobotanica 42(1-2): 207-228.

PawŁowski F., Jędruszczak M. \& Wóscik Z. 1989. Zbiorowiska roślinne ściernisk Lubelszczyzny. II. Zbiorowiska siedlisk bogatych, umiarkowanie wilgotnych i suchych. Acta Agrobotanica 42(1-2): 229-246.

Trąba Cz., PawŁowski F. \& Wójcik Z. 1991. Zbiorowiska roślinne ściernisk na nizinnych kompleksach glebowo-rolniczych południowo-wschodniej Polski. I. Zbiorowiska ze związku Panico-Setarion. Acta Agrobotanica 44(1-2): 87-111.

TrĄBA Cz. \& WóJCIK Z. 1991. Zbiorowiska roślinne ściernisk na nizinnych kompleksach glebowo-rolniczych południowo-wschodniej Polski. II. Zbiorowiska ze związku Eu-Polygono-Chenopodion. Acta Agrobotanica 44(1-2): 113-135.

WasıŁowska A. \& WóJCiK Z. 1995. The vegetation of the transition zones between forest and cultivated fields. Ekol. Pol. 43(1-2): 7-50.

Wóscik Z. 1998. Zbiorowiska segetalne Pogórza Przemyskiego i jego najbliższego otoczenia. Fragm. Flor. Geobot. Polonica 5: 117-164.

WóscıK Z. 2000. Zbiorowiska segetalne Pojezierza Suwalskiego. Fragm. Flor. Geobot. Polonica 7: 167-208.

Wóscık Z. 2001. Oxalido-Chenopodietum polyspermi Sissingh 1942 - zespół chwastów upraw okopowych dolin rzecznych i pogórzy w Polsce. Prace Geograficzne Instytutu Gospodarki i Przestrzennego Zagospodarowania PAN 178: 87-117.

Wóscik Z. 2001. Rozmieszczenie gatunków charakterystycznych zespołu Papaveretum argemones na terytorium Polski. Prace Geograficzne Instytutu 
Gospodarki i Przestrzennego Zagospodarowania PAN 179: 253-262.

Wóscık Z. 2001. Zbiorowiska segetalne Wigierskiego Parku Narodowego. In: A. Richling \& J. Solon (eds.). Struktura i funkcjonowanie Wigierskiego Parku Narodowego, pp. 131-140. Wyd. Akademickie "Dialog”, Warszawa.

\section{Commemorative articles}

Wóscik Z. 1965. Stulecie urodzin Józefa Paczoskiego. Ekol. Pol. B. 11(2): 181-182.

Wóscıк Z. \& Wósciк Zв. 1985. Wspomnienie o Kazimierzu Wójciku (1875-1937). Przegląd Geologiczny 30(7): 419-420.

Wóscik Z. 1985. Z życia harcerek w Afryce lat czterdziestych. In: K. WyCZAŃSKA (ed.). Harcerki 1939-1945. II. Relacje-Pamiętniki. Instytut Historii Polski PAN, pp. 749-760. PWN, Warszawa.

Wósсıк Z. 1997. Afryka lat czterdziestych we wspomnieniach instruktorki harcerskiej. Koło Harcerek i Harcerzy z Lat Dawnych. 58 pp. Londyn.

Wóscik Z. 2003. Z teki wspomnień. In: Aktualne kierunki i perspektywy badań w geobotanice na progu trzeciego tysiąclecia. Konferencja naukowa w setną rocznicę urodzin Profesora Jakuba Mowszowicza. Wkład Profesora Jakuba Mowszowicza w powstanie i rozwój łódzkiej szkoły geobotanicznej. Wyd. Uniwersytetu Łódzkiego, pp. 34-36. Łódź.

Wóscı́ Z. 2013. Wspomnienie o Januszu Bogdanie Falińskim. Wiad. Bot. 57(1-2): 24-27.
WóJCIK Z. 2014. Mój afrykański krzyż harcerski. In: T. SiKORSKI (ed.). Krzyż harcerski 1913-2013. Oficyna Pamiątki Przeszłości "Sikorsky”, pp. 107-111. Warszawa-Kraków.

\section{Popular science papers}

Wóscik Z. 1952. Ewolucja świata roślinnego. In: Opracowanie zbiorowe. Agrotechnika 1: 17-37. PWRiL, Warszawa.

WóscıK Z. 1955. Budowa i życie rośliny. In: Opracowanie zbiorowe. Podstawy rolnictwa. Produkcja i jej organizacja. PWRiL. Warszawa.

SANDNER H. \& Wóscik Z. 1966. Kalendarz przyrody. 399 pp. Wiedza Powszechna, Warszawa.

\section{Manuscripts}

Wóscik Z. 1937. Warunki rozwoju odciętego końca korzenia kukurydzy. Zakład Fizjologii Roślin i Chemii Rolnej. Wydział Rolniczo-Leśny Uniwersytetu Poznańskiego. 33 pp. Praca inżynierska, Poznań.

WósCik Z. 1938. Wyższa roślinność wodna Wielkopolski. Zakład Botaniki Ogólnej. Wydział MatematycznoPrzyrodniczy Uniwersytetu Poznańskiego. 37 pp. M.Sc. Thesis, Poznań.

Wóscıк Z. 1964. Zbiorowiska chwastów zbożowych Mazowsza. Zakład Systematyki i Geografii Roślin. Wydział Biologii i Nauk o Ziemi Uniwersytetu im. Adama Mickiewicza w Poznaniu. Ph. D. Thesis, 159 pp. Poznań. 